\title{
Evaluation by a different method of egg quality in hens $\uparrow$
}

\author{
Ismail Turker (D) 1*, Sezai Alkan (DD 2, Serpil Akcay (D) ${ }^{3}$, Serdar Kamanli (D) 4 \\ ${ }^{1}$ Uşak University, Faculty of Agriculture and Nature Sciences, Department of Animal Science, Uşak, Turkey \\ ${ }^{2}$ Ordu University, Faculty of Agriculture, Department of Animal Science, Ordu, Turkey \\ ${ }^{3}$ Republic of Turkey Ministry of Agriculture and Forestry, General Directorate of Livestock, Ankara, Turkey \\ ${ }^{4}$ Poultry Research Institute, Ankara, Turkey \\ $\uparrow$ Presented as a paper at the $9^{\text {th }}$ National Animal Science Congress.
}

\begin{abstract}
Egg quality is determined by measuring various characteristics of eggs. These characteristics are divided into two parts including exterior and interior quality of the egg. External quality characteristics of egg weight, shape index, shell thickness, breaking strength, egg surface area and internal quality attributes albumen index, yolk index, haugh unit and meat-blood spot. These characteristics are evaluated separately in the egg but there is not an evaluation method covering all characteristics. This is same in eggs notification and the standard.

In this study, to evaluate the level of a single or population of all the features of the eggs are explained a simple way.
\end{abstract}

\section{ARTICLE HISTORY}

Received: 25 May 2020

Accepted: 12 June 2020

\section{KEYWORDS}

Egg

Quality

Haugh unit

Breaking strength

* CORRESPONDING

iturker1071@gmail.com

\section{Introduction}

Egg is a significant food source due to its high biological value. Consumers want a certain standard in egg, as in all foodstuffs. These standards for consumers are characteristics such as the shape, color and internal quality of the egg. Egg quality is divided into two as internal and external qualities. External quality characteristics are the strength of the shell, shell color, deformity, it's cracked or broken and it's being contaminated with feces. Internal quality characteristic is albumen, yolk, meat-blood spots and the nutritional content of the egg (Anonymous, 2015).

In Turkey, eggs are divided into two, including the A and B classes according to TS-1068 Hatching (Chicken) Egg Standard. In these standards, the airspace and haugh unit of egg are taken into account. In addition, the eggs are divided into four groups according to their weight; $\geq 73 \mathrm{~g}$ eggs are very large, 63-72 g are large, 53-62 g are medium and $\leq 52$ are small (Anonymous, 2009).

According to the Turkish Food Codex of the Ministry of Agriculture and Forestry, Class A eggs are described as following.

The eggshell must be clean. The eggshell may be slightly lumpy. The eggshell should be solid, without cracks, without fractures and normal shape.

The airspace in eggs, which is sold as "extra fresh" should not be higher than $4 \mathrm{~mm}$, in others should not be higher than $6 \mathrm{~m}$, and the airspace of the egg should be stable.

Albumen should be clear, transparent and gel-like, free of extraneous.

In light examination, egg yolk should be seen as a round shadow in the center, it should not be clearly separated from the center when rotating the egg and it should not contain extraneous.

There should be no visible embryos in the egg content. It should not contain any extraneous smell (Anonymous, 2014).

In both the TS-1068 and the Egg and Egg Products Communiqué did not include quality assessment about other characteristics that are significant for egg. In fact, the other characteristics that are not related to each other have also a share in egg quality.

The aim of the study is to answer the question "how can the eggs be classifying" by considering and scoring more than one characteristics in both individually and population level

\section{Materials and methods}

The materials of the study consist of the data that obtained from the research conducted about the egg quality; the values of TS-1068 Hen Egg Standard; and the egg quality criteria of the Egg and Egg Products Communiqué. In the study, the egg characteristics such as the shape index, egg weight, shell thickness, shell breaking strength, haugh unit and egg yolk index, which are significant in quality evaluation, taken into account. These characteristics values, which presence in standards and books about poultry husbandry, (Senkoylu, 2001; Sarica and Erensayin, 2009) were accepted as the ideal limit and each characteristic was given 100 points. Since haugh unit is indirectly related to the albumen height and index and is a determining criterion in terms of albumen quality, other characteristics are not included to the study. At the same time, the specific gravity 
was not taken into account as a criteria since there was a similar relationship between the shell thickness and the specific gravity.

Table 1. Egg quality characteristics and their coefficients

\begin{tabular}{lccc}
\hline $\begin{array}{l}\text { Egg Quality } \\
\text { characteristic }\end{array}$ & $\begin{array}{c}\text { Number of } \\
\text { characteristic } \\
(\mathrm{n})\end{array}$ & $\begin{array}{c}\text { Ideal } \\
\text { quality } \\
\text { value } \\
\text { considered } \\
(\mathrm{x})\end{array}$ & $\begin{array}{c}\text { Calculated } \\
\text { coefficient } \\
(\mathrm{i})\end{array}$ \\
\hline Egg weight $(\mathrm{g})$ & 1 & 64 & 1.5625 \\
$\begin{array}{l}\text { Shape index } \\
\text { Shell thickness }\end{array}$ & 1 & 74 & 1.3514 \\
$(\mu \mathrm{m})$ & 1 & 35 & 2.8572 \\
$\begin{array}{l}\text { Egg yolk index } \\
\text { Haugh unit }\end{array}$ & 1 & 48 & 2.0834 \\
Shell thickness & 1 & 80 & 1.2500 \\
$\left(\mathrm{~N} / \mathrm{cm}^{2}\right)$ & 1 & 40 & 2.5000 \\
\hline Total & 6 & & \\
\hline
\end{tabular}

Equation coefficient was created on the following values.

Shape index $=74$

Egg weight $=64 \mathrm{~g}$

Shell thickness $=35 \mu \mathrm{m}$

Breaking strength $=40$ newton

Haugh unit $=80$

Egg yolk index $=48$ values.
Equation coefficient values for each characteristic were found by 100 dividing each ideal value. Then, the coefficients for each characteristic were calculated (Table 1).

When the shape index rises upper the ideal values, it makes an additional contribution to the equation. This will cause a negative value to be reflected positively on the scoring. In order to prevent this situation, when manual processing is wanted to make, if the ideal number (74) is exceeded, low number that is the symmetric in numerical plane will be used in the formula as indicated in Figure 1.

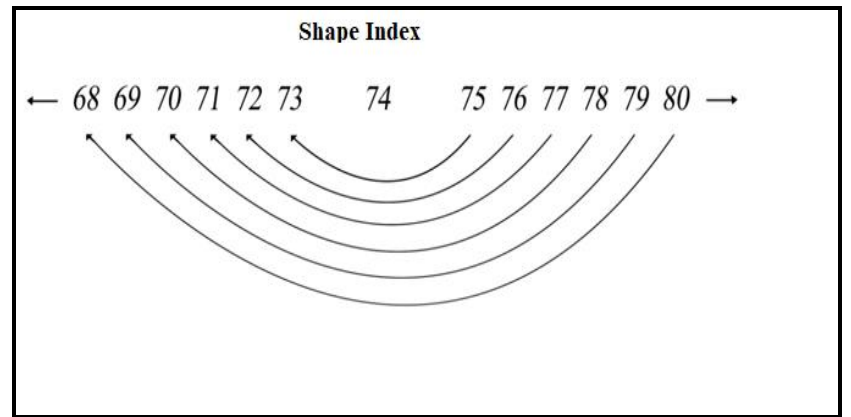

Figure 1. Shape index formula

While computing to compensate for this situation, which is normally a negativity in egg quality, it will be possible to eliminate this negativity in the equation by using the following formula to the data entered in column A in excel program as shown in Figure 2.

$=$ If12<\$D\$2;A12*1,3513;If(A12=\$D\$2;"Optimal";(\$D\$2-(A12-\$D\$2)*1,3513))



Figure 2. Example excel program worksheet for shape index

If the shape index is a number upper than 74, let's assume that it is 75 as an example, the program will give it a result by multiplying 73 . The formula created in Excel program was written by considering this situation. The average of the values obtained by multiplication the coefficients calculated with the values measured of the egg and the value obtained by the effects of the all characteristics for the egg had been evaluated as the egg point. Points can be calculated with the help of the following formula: 
Point $\mathrm{n}=\sum(\mathrm{x} * \mathrm{i}) / \mathrm{n}$

$\mathrm{x}=$ determined egg quality value

$\mathrm{i}=$ coefficient

$\mathrm{n}=$ the number of the characteristic

The point obtained by multiplication the values of the following egg quality characteristics and their coefficients had been taken as the lower limit. These eggs were included in the low quality class.

Shape index $=71$

Egg weight $=52 \mathrm{~g}$

Shell thickness $=29 \mu \mathrm{m}$

Breaking strength $=20$ Newtons

Haugh unit $=52$

Egg yolk index $=45$

Table 2. Calculated lower and upper points of egg quality

\begin{tabular}{|c|c|c|c|c|c|c|}
\hline $\begin{array}{l}\text { Egg } \\
\text { characteristics }\end{array}$ & Upper quality value & Coefficient & $\begin{array}{l}\text { Total quality } \\
\text { upper value }\end{array}$ & Lower quality value & Coefficient & $\begin{array}{l}\text { Total lower } \\
\text { quality value }\end{array}$ \\
\hline Egg weight (g) & 64 & 1.5625 & 100.00 & 52 & 1.5625 & 81.25 \\
\hline Shape index & 74 & 1.3514 & 100.00 & 71 & 1.3514 & 95.95 \\
\hline Shell thickness $(\mu \mathrm{m})$ & 35 & 2.8572 & 100.00 & 29 & 2.8572 & 82.86 \\
\hline Egg yolk index & 48 & 2.0834 & 100.00 & 45 & 2.0834 & 93.75 \\
\hline Haugh unit & 80 & 1.2500 & 100.00 & 52 & 1.2500 & 65.00 \\
\hline Breaking strength $(\mathrm{N} / \mathrm{cm} 2)$ & 40 & 2.5000 & 100.00 & 20 & 2.5000 & 50.00 \\
\hline Score $=$ Total quality value $/ 6=$ & & & 100 & Score $=$ Total qua & value $/ 6=$ & 78.13 \\
\hline
\end{tabular}

In case the proposed egg quality method is accepted, the convenience will be provided in terms of revealing the net results as a result of scientific researches to determine the egg quality in hens. Research can be carried out taking into account all other characteristics, but it is thought that it will be significant to express the egg quality as an average quality value by considering the specified characteristics of the population examined. In addition, it is believed that the described method will facilitate the measurement of the quality of the eggs put on the market by the egg producer companies and the expression of the egg quality.

Table 3. The creation of egg quality groups

\begin{tabular}{ccc}
\hline Groups & Class & Score \\
\hline 1 & A & $90-100$ \\
2 & B & $80-89$ \\
3 & C & $\leq 79$ \\
\hline
\end{tabular}

As a result, the proposed quality measurement method is expected to be meaningful for the poultry sector, researchers and consumers because it will allow it to be expressed by creating under the influence of all the characteristics that are important for the measurement and evaluation of egg quality.

\section{Results}

The upper and lower egg points calculated for the egg characteristics examined in the study were given in Table 2 . According to the egg points, it will be appropriate to divide the quality into three classes. In Table 2 , it was determined that the upper values of the eggs were 100 and the lower values were 78.13. In this case, the creation of the point sheet for the three egg quality classification as given in the table 3 is very significant in terms of revealing the egg quality more clearly.

\section{Discussion}

As can be seen in the Table 2, the multiplication of the upper egg quality characteristics and their calculated quality coefficients will be equal to 100 . It will be seen that the average of these values is 100 , which is the upper limit point. The eggs, which have this value and lower values, can be evaluated as low quality.

\section{Authors' Contributions}

I.T. Developing the concept and assumptions, developing the method conducting the studies, performed interpreted the data and wrote the manuscript. S.A., S.K. and S.A. other contribution. All authors commented on the results and the manuscript.

\section{Conflict of Interest}

The authors declare that they have no conflict of interest.

\section{References}

Anonmous. (2009). TS-1068 Tavuk yumurtas1-kabuklu. Türk Standartları Enstitüsü-Türk Standardı.

Anonmous. (2014). Tarım ve Orman Bakanlığı Türk Gıda Kodeksi, Yumurta Tebliği, Tebliğ No: 2014-55.

Anonmous. (2015). Yumurta kalitesi. http://hayvancilikakademisi.com/egitim/yazarlar Egitim/yumurtaci-tavuklarda-beslenme-ve-yumurtakalitesi/ (07-04-2015).

Sarica, M., \& Erensayin, C. (2009). Tavukçuluk ürünleri. Tavukçuluk Bilimi yetiştirme, besleme, hastalıklar. Bey ofset, 3. basım, Ankara, S: 588.

Senkoylu, N. (2001). Modern Tavuk Üretimi. Anadolu Matbaas1, 3. Bask1, İstanbul, S:538. 